\title{
The Role of Financial and Managerial Variables on the Policy towards Home-grown Players in English Soccer
}

\author{
Carlo Amenta ${ }^{1}$, Claudio Ballor ${ }^{2} \&$ Paolo Di Betta ${ }^{3}$ \\ ${ }^{1}$ DISMOT Department, University of Palermo, Italy \\ ${ }^{2}$ Manager at IAMS (Infront Advanced Media Solutions), Milan, Italy \\ ${ }^{3}$ SEAF Department, University of Palermo, Italy \\ Correspondence: Paolo Di Betta, University of Palermo, viale delle Scienze edificio 15, 90138 Palermo, Italy. \\ Tel: 39-91-2389-5308. E-mail: paolo.dibetta@unipa.it
}

Received: August 27, 2012

Accepted: September 19, 2012

Online Published: October 16, 2012

doi:10.5539/ibr.v5n11p28

URL: http://dx.doi.org/10.5539/ibr.v5n11p28

\begin{abstract}
The training and development of young players both as athletes and individuals is one of the task soccer governing bodies assign to professional soccer team in order to fully exploit the social aspects of sport activities. Recently UEFA imposed new rules to improve the use of home-grown players. We analyze a panel data of English Premier and Championship league clubs for the seasons 2001-02 to 2005-06 in order to understand what clubs characteristics lead to the employment of young players in the team during official matches. Sport commercialization and the employment of star players have been considered harmful to this role. Our findings suggest that, counter-intuitively, economic and commercial aspects of clubs are not important for the development of home-grown players, for example well paid players do not crowd-out home-growns. Managerial policies play a significant role. Major clubs in the Premier league deploy home-grown less often; leasing them to the Championship league could be a solution. Attendance favors home-grown players, which hints at a more active communication policy for the clubs in order to nurture the link with the local community. These results suggest social responsible strategies for Premier League clubs in order to improve their perceived social role and to avoid invasive interventions from national and international governing bodies in their managerial decisions on the clubs.
\end{abstract}

Keywords: sport governing bodies, soccer club management, corporate social responsibility in sports

\section{Introduction}

Political institutions are very much concerned on education and training of the young athlete, these are considered areas in which to implement active policies with the aim to pursue a societal role for sport. The European Commission (2007, p. 7) "emphasises the importance of taking into account at an early stage the need to provide 'dual career' training for young sportsmen and sportswomen and to provide high quality local training centres to safeguard their moral, educational and professional interests". Therefore, the training and development of young athlete should be devoted not only to the quest for talent but also in empowering the character of the individual and to leaving open other alternatives for the future.

Nurturing the young athlete is another area of interest in which political institutions have requested sport governing bodies to be active in guiding professional teams, oftentimes generating discontent. One of these policies require teams to preserve a quota to locally trained players, as fostered by the European Commission. The UEFA ensued and has adopted this rule in season 2006-2007 by requiring that clubs participating in the Champions League and the UEFA Cup must have a minimum number of "home-grown players" in their team. UEFA (2006, ch. VIII, Player Eligibility) defines home-grown players those who have been trained by their club or by another club in the national association for at least three years between the age of 15 and 21, regardless of their nationality or age. European professional soccer clubs opposed this ruling on the basis that it is not compatible with free movements of persons inside the European Union. As a reply, the European Commission commissioned an independent study (INEUM \& TAJ, 2008) supporting the compatibility of the rule with European treaties, provided that it does not lead to any direct discrimination based on nationality. It is also sustained that any eventual indirect discrimination effects, resulting from this rule, can be justified as 
proportionate to the legitimate objective which is pursued (to enhance and protect the training and development of talented young players). The European White Paper on sport ended the legal dispute by including the rule in its conclusions.

The fierce reaction by European professional soccer clubs has re-opened the never-sedated tug-of-war between those who consider detrimental the role of marketing strategies in professional sport and the employment of star players when societal aims are pursued. The case just shown has been another lost opportunity. Not only European soccer clubs did not obtain any success against the UEFA ruling, but their reaction has also been perceived as another confirming instance of their typical attitude of lack of attention to societal aspects of sport.

The general opinion is that professional soccer clubs are greedy. They show limited interest in corporate social responsible policies due to increasing commercialization and industrialization of an otherwise beautiful sport. It is common wisdom that the more money is poured in the field, the more star players are paid, the less home-grown athletes have a chance to play.

There is only anecdotic evidence to support this idea. By conducting a panel data analysis on 53 English professional soccer teams in seasons from 2001-02 to 2006-06 we have tried to understand whether this belief is supported by empirical analysis.

The research question is centered on the role exerted by economic and financial conditions of the club as opposed to sporting variables in limiting employment of home-grown players. How relevant are economic, financial and commercial characteristics of soccer clubs for the development of home-grown players as opposed to sporting factors? The literature on sporting production function is overwhelming, so we refer the reader to two papers on the same leagues as ours: Dawson et al. (2000) for a complete, even though not updated review, and Haas (2003) for an evaluation of English Premier League clubs' productive efficiency.

The results imply a clear-cut strategy in corporate social responsibility (CSR) for the Premier League professional clubs in order to change the general perception of greedy clubs and opaque image as non caring organizations. These strategies could also pre-empt the imposition of strict rules by governing bodies that heavily affect decisions on the sporting and the managerial side of the business.

Whereas the literature on CSR strategies has grown fast in managerial studies (Lockett, Moon, \& Visser, 2006), CSR in sports has lacked behind. Very few papers explicitly address CSR as related to sport business and it seems that CSR does not play a significant role in sport (Kott, 2005). Breithbart and Harris (2008) develop a conceptual model which incorporates a broad definition of CSR and apply it to football business. Babiak and Wolfe (2006) analyze the relationship between CSR strategies and a major sport event. Lau, Makhanya and Trengrose (2006) analyze CSR policies activated by some sport governing bodies. Amenta and Di Betta (2010) derive CSR strategies to be applied on ticket price fixing for Italian professional soccer clubs.

The concept links the idea of business as being part of the society to ethical ways of conducting business, but it is still quite broadly defined, so that even today we can agree with Votaw $(1972$, p. 25) that: "corporate social responsibility means something, but not always the same thing to everybody". Garriga and Melè (2004) tried to put order among several theories by highlighting four perspectives on CSR: instrumental, political, integrative, ethical. We focus on the role of professional soccer clubs in caring and nurturing young athletes and we analyse integrative theories which consider that business ought to integrate social demands. According to Garriga and Mele $(2004,2)$ theorists in this stream of the literature "usually argue that business depends on society for its continuity and growth and even for the existence of business itself". By fostering inclusion, development and education of young players, professional teams both invest in human capital for their business but also increase their demand and market size. Young players will always be soccer fans, thus contributing to the growth in interest on the sport and therefore inducing a positive attitude towards the game.

Soccer team can be an interesting field study to analyze CSR strategies as a constitutive component of a professional soccer club's business strategy. We focus on home-grown players, who have received constant attention by political institutions and sport governing bodies. The literature on soccer is well aware of the important role of home-grown players. Szymansky and Kuypers (1999) define home-grown players as those who sign with the club without ever having registered with another one. They notice that on average 45 percent of players in the leagues are home-grown, and clubs in higher position tend to develop talent more than lower-league-positioned clubs do. Gerrard $(2004$, p. 80$)$ shows that a major source of the team's success in the sporting domain "has been its development of a group of highly talented home-grown players who have contributed to a high level of shared experience and continuity that rival clubs have been unable to match over a sustained period". A growing number of psychological studies specifically consider young athletes in order to investigate motivations and incentives (Laurin et al., 2008; Williams \& Reilly, 2000). 
Despite the conspicuous number of papers focussing on sport production function, home-growns are never explicitly included among the regressors in econometric models. Berman et al. (2002) compare performances and teams' home-grown rates in the U.S. National Basketball Association. It seems that no one has explicitly investigated issues connecting home-grown players and economic and sporting variables, in any sport. This is the first paper in which they are considered as dependent variable in order to understand which are the drivers and the extent of their employment.

Our research question regards investigating the impact of economic and financial variables, as opposed to managerial variables, on the policy towards home-grown players, which is a preeminent socially responsible strategy. If managerial variables were relevant, then one could investigate how the policy on home-grown players could be communicated to the community and to the regulatory bodies, thus becoming part of an active social responsible strategy.

The structure of the paper is as follows. In section 2 we illustrate the dataset and the estimation procedure, in section 3 we comment upon the results. In the concluding section we derive some implications for a well defined socially responsibile policy for English clubs.

\section{Method}

We built up a panel data on English soccer professional teams, from Premier and Championship League, for seasons from 2001-02 to 2005-06. The panel is unbalanced due to the process of relegation from Championship league that causes some team in certain seasons to be dropped from the panel altogether. Our dataset consist of 53 observations for 5 seasons, for a total number of 265 observations. We have data for each season and each team in the $62 \%$ of the sample. The remaining observations concern 46 teams. The main sources for data where the Deloitte Report (2001, 2002, 2003, 2004, 2005, 2006) and www.soccerbase.com.

Each variable is indexed by $c$ and $s$ to represent club and season. The dependent variable is $\mathrm{HG}_{\mathrm{c}, \mathrm{s}}$, it measures the employment of home-grown players as a percentage, calculated by dividing the number of matches in which they appear in the starting roster on the the total possible caps per season (obtained by multiplying the total number of matches per season times the number of players that start the match, 11 for each team). A home-grown in the starting roster is a strong signal that the team managerial board is committed to develop young players.

We individuate three groups of regressors: sporting, economics and managerial, whose descriptive statistics can be found in Table 1 .

Sporting variables include POINTS $_{\mathrm{c}, \mathrm{s}}$ (points scored), WAGES $_{\mathrm{c}, \mathrm{s}}$ (wages and salaries) and a dummy to indicate a club in the Premier league, DPREMIER ${ }_{c, s}$. POINTS is the total number of points at the end of season. One expects, as a general belief, an inverse relationship between POINTS and home-grown players, namely, that the stronger (and richer) teams employ less home-grown players. The "total of staff emoluments as disclosed in the notes to the accounts" (Deloitte 2007, Appendices 4) is WAGES. We consider it as a proxy for team quality and attractiveness. Therefore one would expect to obtain a negative relationship also from WAGES, because the presence of well paid and superstar players should reduce the chance for home-grown to play. The dummy variable indicates whether the team is playing in the Premier League. One expects that teams in the Premier league (DPREMIER=1) employ fewer grassroots players than Championship league, so we expect a negative sign for this variable.

Economic and financial variables are: pre-tax profit (or loss) PROFIT $\mathrm{c}_{\mathrm{c}, \mathrm{s}}$ and net assets (liabilities), ASSETLIAB $_{c, s}$. Pre-tax profit (loss) is the economic result for the season found in various editions of Deloitte review. We also consider the short term financial equilibrium of the club. Current assets include cash and other assets turned into cash in one year and liabilities are obligations due and payable within 12 months; ASSETLIAB is the difference between the two. Both variables measure the short term financial strength of the club, so we expect to find an inverse relationship, because richer teams are believed to employ fewer home-grown players.

Managerial variables are ATTENDANCE $\mathrm{c}_{\mathrm{c}, \mathrm{s}}$, PLAYERSIN $_{\mathrm{c}, \mathrm{s}}$ and PLAYERSOUT $\mathrm{C}_{\mathrm{c}, \mathrm{s}}, \mathrm{CHANGE}_{\mathrm{c}, \mathrm{s}}$. ATTENDANCE is average stadium attendance per season; we expect an inverse relationship because it is a proxy for the importance of the team. The total number of players acquired in the season is PLAYERSIN, whereas PLAYERSOUT is the number of dismissed ones. We expect negative impact from the former, because new players acquired reduce the chance that home-growns will play, and on the contrary we expect a positive influence from the latter. CHANGE counts the number of manager team changed per season. We expect a change in the manager to affect negatively the possibility of home-grown to play because the new manager might follow the less risky route to let the elder athletes to play more. 
Table 1. Descriptive statistics

\begin{tabular}{|c|c|c|c|c|c|c|c|}
\hline \multirow{2}{*}{$\begin{array}{l}\text { Variable } \\
\mathrm{HG} \%\end{array}$} & \multirow[b]{2}{*}{ overall } & \multirow{2}{*}{$\begin{array}{l}\text { Mean } \\
0.176243\end{array}$} & \multirow{2}{*}{$\begin{array}{l}\text { Std. dev. } \\
0.119082\end{array}$} & \multirow{2}{*}{$\begin{array}{l}\text { Min } \\
0\end{array}$} & \multirow{2}{*}{$\begin{array}{l}\text { Max } \\
0.743\end{array}$} & \multicolumn{2}{|c|}{ Observations } \\
\hline & & & & & & $\mathrm{N}$ & 220 \\
\hline & between & & 0.107846 & 0.0158 & 0.53205 & $\mathrm{C}$ & 53 \\
\hline & within & & 0.058159 & -0.01344 & 0.387193 & S-bar & 4.15094 \\
\hline \multirow[t]{3}{*}{ WAGES } & overall & 23.50505 & 21.18692 & 2.692 & 114.784 & $\mathrm{~N}$ & 207 \\
\hline & between & & 19.74668 & 2.88225 & 89.591 & $\mathrm{C}$ & 49 \\
\hline & within & & 6.453806 & -11.7209 & 48.69805 & S-bar & 4.22449 \\
\hline \multirow[t]{3}{*}{ PROFITS } & overall & -31.8629 & 204.2344 & -965 & 946 & $\mathrm{~N}$ & 203 \\
\hline & between & & 149.7317 & -284.12 & 739 & $\mathrm{C}$ & 49 \\
\hline & within & & 170.7843 & -806.164 & 716.8361 & S-bar & 4.14286 \\
\hline \multirow[t]{3}{*}{ ASSETLIAB } & overall & 18.30285 & 154.839 & -824 & 977 & $\mathrm{~N}$ & 204 \\
\hline & between & & 184.9241 & -774 & 897 & $\mathrm{C}$ & 49 \\
\hline & within & & 99.42993 & -355.691 & 791.9739 & S-bar & 4.16327 \\
\hline \multirow[t]{3}{*}{ ATTENDANCE } & overall & 24.54721 & 12.90485 & 2.786 & 68.765 & $\mathrm{~N}$ & 220 \\
\hline & between & & 12.75534 & 4.831667 & 67.8986 & $\mathrm{C}$ & 53 \\
\hline & within & & 2.354066 & 15.27341 & 33.92521 & S-bar & 4.15094 \\
\hline \multirow[t]{3}{*}{ CHANGE } & overall & 0.459091 & 0.778219 & 0 & 3 & $\mathrm{~N}$ & 220 \\
\hline & between & & 0.488286 & 0 & 2 & $\mathrm{C}$ & 53 \\
\hline & within & & 0.657529 & -0.94091 & 2.709091 & S-bar & 4.15094 \\
\hline \multirow[t]{3}{*}{ PLAYERSIN } & overall & 7.013636 & 3.52872 & 0 & 19 & $\mathrm{~N}$ & 220 \\
\hline & between & & 2.488897 & 3.2 & 15 & $\mathrm{C}$ & 53 \\
\hline & within & & 2.719217 & -0.98636 & 17.61364 & S-bar & 4.15094 \\
\hline \multirow[t]{3}{*}{ PLAYERSOUT } & overall & 6.456621 & 4.023063 & 0 & 22 & $\mathrm{~N}$ & 219 \\
\hline & between & & 2.846756 & 1 & 16 & $\mathrm{C}$ & 53 \\
\hline & within & & 3.143692 & -0.34338 & 21.85662 & S-bar & 4.13208 \\
\hline \multirow[t]{3}{*}{ DPREMIER } & overall & 0.454546 & 0.499065 & 0 & 1 & $\mathrm{~N}$ & 220 \\
\hline & between & & 0.428391 & 0 & 1 & $\mathrm{C}$ & 53 \\
\hline & within & & 0.255234 & -0.34545 & 1.254545 & S-bar & 4.15094 \\
\hline \multirow[t]{3}{*}{ POINTS } & overall & 58.01364 & 16.3446 & 15 & 106 & $\mathrm{~N}$ & 220 \\
\hline & between & & 10.40672 & 26 & 81.25 & $\mathrm{C}$ & 53 \\
\hline & within & & 13.02379 & 23.61364 & 102.6136 & S-bar & 4.15094 \\
\hline \multirow[t]{3}{*}{ HGN } & overall & 5.145455 & 3.20056 & 0 & 19 & $\mathrm{~N}$ & 220 \\
\hline & between & & 2.914114 & 1 & 13 & $\mathrm{C}$ & 53 \\
\hline & within & & 1.790279 & 0.345455 & 11.81212 & S-bar & 4.15094 \\
\hline \multirow[t]{3}{*}{ TURNOVER } & overall & 37.06626 & 36.79261 & 3.22 & 174.936 & $\mathrm{~N}$ & 207 \\
\hline & between & & 34.62565 & 4.23575 & 164.3262 & $\mathrm{C}$ & 49 \\
\hline & within & & 8.870319 & 3.677264 & 66.36426 & S-bar & 4.22449 \\
\hline
\end{tabular}

Note: $\mathrm{N}$ is total numer of observations, $\mathrm{C}$ number of clubs, S-bar is average season presence.

Since sporting performance is itself influenced by the presence of home-grown players, we must treat points as an endogenous variable (this regressor is correlated with the time-varying component of the error). The number of home-grown players $\mathrm{HGN}_{\mathrm{c}, \mathrm{s}}$ and total revenues TURNOVER $\mathrm{c,s}$ are used as additional (excluded) instruments to explain POINTS.

\section{Results}

We run a two-stage least square fixed-effects panel regression for $\mathrm{HG} \%$, with an endogenous variable POINTS (Cameron \& Trivedi, 2009; Schaffer, 2007). The model, which we estimate without a constant, is as follows:

$$
\begin{gathered}
H G \%_{c, s}=\beta_{1} \text { POINTS }_{c, s}+\beta_{2} \text { WAGES }_{c, s}+\beta_{3} \text { PROFITS }_{c, s}+\beta_{4} \text { ASSETLIAB }_{c, s}+\beta_{5} \text { ATTENDANCE }_{c, s}+ \\
\beta_{6} \text { CHANGE }_{c, s}+\beta_{7} \text { PLAYERSIN }_{c, s}+\beta_{8} \text { PLAYERSOUT }_{c, s}+\beta_{9} \text { DPREMIER }_{c, s} \\
\text { POINTS }_{c, s}=\gamma_{1} \text { HGN }_{c, s}+\gamma_{2} \text { TURNOVER }_{c, s}+e_{c, s}
\end{gathered}
$$

Equation (1) is what we estimate in the second stage, whose results are reported in Table 2. Equation (2) is the first-stage regression for the endogenous variable POINTS, with the two excluded instruments HGN and TURNOVER, while $\varepsilon_{\mathrm{c}, \mathrm{s}}$ and $\mathrm{e}_{\mathrm{c}, \mathrm{s}}$ are the error terms. Equation (2) is a very simple model in which sporting results depend on the economic dimension of the club and home-grown players. Recall also that in the first stage all the 
included regressors are present. We do not report the results, but we can tell that all the variables are not significative, except for the change in manager, the number of home-grown players, the dummy for Premier league, and the level of players acquired, which are significative and have a negative impact on the instrumented variable POINTS.

Table 2. Results of the regression for $\mathrm{HG} \%$

\begin{tabular}{|c|c|}
\hline Regressors & Coefficients \\
\hline POINTS & $\begin{array}{l}-0.01008 \\
(0.002151)^{* * *}\end{array}$ \\
\hline WAGES & $\begin{array}{l}0.003721 \\
(0.001455)^{* *}\end{array}$ \\
\hline PROFITS & $\begin{array}{l}-2.3 \mathrm{E}-05 \\
(3.34 \mathrm{E}-05)\end{array}$ \\
\hline ASSETLIAB & $\begin{array}{l}3.39 \mathrm{E}-05 \\
(4.85 \mathrm{E}-05)\end{array}$ \\
\hline ATTENDANCE & $\begin{array}{l}0.011528 \\
(0.00467)^{* *}\end{array}$ \\
\hline CHANGE & $\begin{array}{l}-0.02509 \\
(0.014779)^{*}\end{array}$ \\
\hline PLAYERSIN & $\begin{array}{l}-0.0109 \\
(0.003294)^{* * *}\end{array}$ \\
\hline PLAYERSOUT & $\begin{array}{l}0.000907 \\
(0.003013)\end{array}$ \\
\hline DPREMIER & $\begin{array}{l}-0.51327 \\
(0.101815)^{* * *}\end{array}$ \\
\hline c (clubs): 46 & Observations: 199 \\
\hline $\begin{array}{l}\text { Season obs } \\
\text { per Club }\end{array}$ & $\begin{array}{l}\operatorname{Min}=2, \operatorname{Max}=5 \\
\operatorname{Avg}=4.3\end{array}$ \\
\hline$\sigma \_u=.106$ & $\begin{array}{l}F(9,144)=3.66 \\
\text { p-value }=0.0004\end{array}$ \\
\hline$\sigma \_\varepsilon=.108$ & $\rho=.489$ \\
\hline
\end{tabular}

Description: Intrumental variables fixed effects panel data regression. Results from the $2^{\text {nd }}$ stage. Dependent variable: $\mathrm{HG}_{0}$, home-grown players in the starting team, as \% of games per season. Robust std. errors in parenthesis. $\sigma_{-} u$ is the standard deviation of $u_{i}, \sigma_{-} \varepsilon$ is the standard deviation of $\varepsilon_{i}, \rho$ is the fraction of variance due to $u_{i}$. significant at $10 \%, * *$ at $5 \%$, *** at $1 \%$.

We use a robust standard error because the preliminary Breusch-Pagan Lagrange multiplier test (Cameron \& Trivedi, 2009, pp. 96-97) shows heteroschedastic standard errors. The fixed effect model is preferred to a random effect because in a soccer championship it is more realistic to assume that the regressors are correlated with the errors in the regression (which represent the variables not included in the model).

We run an instrumental variable estimation due to endogeneity of POINTS by the obvious fact that players, home-growns included, determine points. Instruments (HGN and TURNOVER) are relevant, because the F-test shows that $\mathrm{F}(2,143)=12.24$ (with $\mathrm{p}$-value $=0.000$ ), a value higher than 10 , the rule-of-thumb cut-off value (Stock \& Yogo, 2005). Instrumental variables are exogenous: the Hansen overidentification J-test is satisfactory (it does not refuse the null with a p-value of 0.4932 ). The F-test that all individual effects are zero is strongly rejected.

In Table 2 we also report $\sigma_{u}$, the standard deviation of individual effects $u_{c}$, the standard deviation of the error term $\varepsilon_{c}, \sigma_{\varepsilon}$, and $\rho$, the fraction of variance due to the individual effects $u_{c}$. These are calculated with a similar regression without imposing the robust estimator of the variance-covariance matrix and with a constant term included.

Results show that economic and financial variables do not matter, while managerial variables do. Managerial change has a negative impact as predicted, apparently the change induces a more conservative policy to employ well-known players. More audience likes more young players and increasing the number of players acquired from other clubs decreases the probability that home-grown will play, whereas increasing the number of players sold does not bear an implication in letting the young play. This can be a hint towards a "honest" purpose in 
nurturing home-growns: an attentive policy to raise them is not aimed at increasing their selling potential. This aspect deserves more investigation. It seems that a link with the community is activated.

As for the sporting variables, notice the counter-intuitive results that well-paid players and superstars are not an obstacle for home-growns to play. However, more successful teams and Premier league clubs have fewer home-growns in their starting teams.

\section{Discussion}

Our results contradict common wisdom that richer clubs have a less attentive policy towards home-grown players, because economic and financial variables do not matter. Moreover, high wages positively influence the probability that home-growns play. It is not true that increasing commercialization is detrimental to young players. Apparently, there is an incentive at work, according to which clubs look for young talent to lower expenditure on star players. Notice also that it seems that the purpose is not to sell them.

However, the Premier league club is lazier towards home-grown as opposed to the Championship mate: major clubs in the Premier league deploy home-grown less often. Lending them to the minor league could be a solution: this can be vested as CSR strategy. We suggest Premier club to lease home-growns to Championship clubs. The same policy should be followed by clubs with a strong winning streak: they show fewer home-grown in their starting teams the higher the points gained. That talent deserves to be nurtured and employed. By lending promising home-grown players to minor teams, the more relevant clubs could demonstrate their caring for the social aspect of sport, because they risk the early exposure of a young talent in order to allow him to test his capacity on the field.

The Football Association (FA) could introduce a minimum number of home-grown for Championship, a policy to reinforce what is already being done. Incentives can be also fostered through a partial redistribution of television rights connected to home-grown players. This policy could be justified by the positive impact exerted by attendance. We think this aspect deserves further investigation.

We suggest that, because managerial variables matter, Championship clubs and Championship league could exploit the differential treatment they reserve to home-growns by using it in their communication strategy towards the general public. They should openly declare their more virtuous policy towards home-grown. This strategy will build a more sound image of clubs that take care of the future of sports. A less greedy image will result that will meet the favour of sporting people and attract young talent and reinforce the link with the community.

\section{Acknowledgements}

Amenta is responsible for section 1, Ballor for section 4, Di Betta for section 3. Section 2 was written together. The database was set up by Ballor in 2007 for his thesis for the Master of Advanced Studies in Sport Administration and Technology, University of Lausanne (Switzerland).

\section{References}

Amenta, C., \& Di Betta, P. (2010). You Can Even Walk Alone: Stadium Attendance and Professional Soccer Clubs' Social Role. International Business and Management, 1(1), 69-79.

Babiak, K., \& Wolfe, R. (2006). More Than Just a Game? Corporate Social Responsibility and Super Bowl XL. Sport Marketing Quarterly, 15, 214-222.

Berman, S. L., Down, J., \& Hill, C. W. L. (2002). Tacit knowledge as a source of competitive advantage in the national basketball association. Academy of Management Journal, 45(1), 13-31. http://dx.doi.org/10.2307/3069282

Breithbart, T., \& Harris, P. (2008). Corporate Social Responsibility in the Soccer Business: Towards the Development of a Conceptual Model. European Sport Management Quarterly, 8(2), 179-206. http://dx.doi.org/10.1080/16184740802024484

Cameron, A. C., \& Trivedi, P. K. (2009). Microeconometrics Using Stata. College Station TX USA: Stata Press.

Dawson, P., Dobson, S., \& Gerrard, B. (2000). Estimating Coaching Efficiency in Professional Team Sports: Evidence from English Association Football. Scottish Journal of Political Economy, 47(4), 399-421. http://dx.doi.org/10.1111/1467-9485.00170

Deloitte. (2001, 2002, 2003, 2004, 2005, 2006). Annual Review of Football Finance.

European Commission. (2007, July 11). White Paper on Sport. 
Garriga, E., \& Melè, D. (2004). Corporate Social Responsibilities Theories: Mapping the Territory. Journal of Business Ethics, 53, 51-71. http://dx.doi.org/10.1023/B:BUSI.0000039399.90587.34

Gerrard, B. (2004). Why Does Manchester United Keep Winning on and off the Field? A Case Study of Sustainable Competitive Advantage in Professional Team Sports. In Andrews, D. L. (Ed.), Manchester united. A Thematic Study (pp. 65-86). London UK: Routledge. http://dx.doi.org/10.4324/9780203412978_chapter_4

Haas, D. (2003). Productive Efficiency of English Footbal Teams - A Daat Development Analysis Approach. Managerial and Decision Economics, 24, 403-10. http://dx.doi.org/10.1002/mde.1 105

INEUM Consulting, \& TAJ. (2008). European Commission Study on training of young sportsmen/women in Europe, June.

Kott, A. (2005). The Philantropic Power of Sport. Foundation News and Commentary. January/February, 20-25.

Lau, N., Makhanya, K., \& Trengrouse, P. (2006). The Corporate Social Responsibility of Sports Organization. In Manfredi, F. (Ed.), Football and Its Future (pp. 43-93). Milan Italy: EGEA.

Laurin, R., Nicolas, M., \& Lacassagne, M. F. (2008). Effects of a Personal Goal Management Program in School and Football Self-Determination Motivation and Satisfaction of Newcomers within a Football Training $\begin{array}{lllll}\text { Centre. European Sport } & \text { Management }\end{array}$ http://dx.doi.org/10.1080/16184740701814431

Lockett, A., Moon, J., \& Visser, W. (2006). Corporate Social Responsibility in Management Research: Focus, Nature, Salience and Sources of Influence. Journal of Management Studies, 43(1), 115-136. http://dx.doi.org/10.1111/j.1467-6486.2006.00585.x

Schaffer, M. E. (2007). xtivreg2: Stata Module to Perform Extended IV/2SLS, GMM and AC/HAC, LIML, and k-class Regression for Panel Data Models. Statistical Software Components S456501, Boston College Department of Economics. http://ideas.repec.org/c/boc/bocode/s456501.html.

Stock, J. H., \& Yogo, M. (2005). Testing for Weak Instruments in Linear IV Regression. In Andrews, D. W. \& Stock, J. H. (Eds.), Identification and Inference for Econometric Models: Essays in Honor of Thomas Rothenberg (pp. 80-108). Cambridge University Press. http://dx.doi.org/10.1017/CBO9780511614491.006

Szymansky, S., \& Kuypers, T. (1999). Winners and Losers. The Business Strategy of Football. London UK, Viking.

UEFA. (2006). Regulations of the Uefa Cup. Retrieved on 10/12/2008 from http://www.uefa.com/multimediafiles/download/regulations/uefa/others/70/22/70/702270_download.pdf.

Votaw, D. (1972). Genius Became Rare: A Comment on the Doctrine of Social Responsibility Pt 1. California Management Review, 15(2), 25.

Williams, A. M., \& Reilly, T. (2000). Talent Identification and Development in Soccer. Journal of Sport Sciences, 18, 657-667. http://dx.doi.org/10.1080/02640410050120041

Note

Note 1. www.soccerbase.com. 